\title{
Conflict management strategy adopted in community forestry of Nepal: a study of four community forests in midwestern region
}

\begin{abstract}
G.R. Acharya ${ }^{1}$, Y. Yasmi $^{2}$
This study focuses on two types of conflicts in Community Forest User Group (CFUG): conflict between User Group Committee (UGC) and user, conflict among users. Users were found impaired from the UGC decisions and their pattern of benefit sharing. Conflict also existed among users. Major strategies adopted to manage conflict were found to be either avoiding or forcing; but avoiding is the most widely used strategy. Moreover compromising and accommodating were found less frequently compared to forcing and collaborating that were rarely used. This study challenges the common perception that community forestry of Nepal is successful in managing its conflict. The findings of this study do not support this claim because collaborating strategy has rarely been used in Community Forest (CF) conflict management. In contrast, this study shows that avoiding and forcing were more commonly used. The greater application of avoiding and forcing strategy in conflict management indicates that CF is still lagging in realizing the best possible option of collaborating. This finding also challenges the effectiveness of the existing conflict management mechanism in CF. This study also suggests collaborating strategy as a better option for managing conflict. On the other hand, this study also reveals that CF is not benefiting the poor of the community. Though, many scholars trumpet CF as a successful programme in Nepal, this study points out that CF has not yet been able to manage its conflicts in a more constructive way. The study also pinpoints short comings of existing conflict management strategies that could be addressed to improve its performance in the days to come.
\end{abstract}

Key words: Benefit sharing, community forestry, conflict, strategy

C ommunity forestry is the main strategy in Nepal's forestry sector policy (Nightingale, 2003; Chhetri, 2006; Acharya, 2002b, Acharya, 2007b). There is a close linkage between forestry and rural people in Nepal where people from rural area mostly depend on the forest resource to meet their fuel wood, fodder and timber need. Over $95 \%$ of the Nepali populace directly depends on the forests for their need of timber and non-timber forest products (Gautam, 2006). This high forestry dependency among people makes country's forest sector always an important issue for the successful implementation of CF in Nepal (Bhattarai, 2006).

CF is claimed by many as one of the most successful programmes in Nepal (Pokharel, 2001; Pandit and Thapa, 2004; Gilmour and Fisher, 1991; Chhetri, 2006). It has become effective in addressing livelihood of the community and conservation issues together and received attention as a successful forest resource management model (Pokharel, 2001; Agrawal and Ostrom 2001; Chakraborty 2001) both nationally and internationally.

Despite the success in the implementation of CF, there are number of conflict related challenges. CF is not free from discussion and debate (Banjade et.al. 2006, Acharya, 2007a Chakraborty, 2001). It has been a potential area for natural resource related conflict. It is true that $\mathrm{CF}$ is one of the successful programmes in Nepal (Pokharel, 2001; Fisher, 1995) but different findings point out that there is an existence of different types of conflicts in the CF (Rana, 2004; Shrestha, 1996; Joshi, Undated, Uprety, 2006). CF needs effective management (Pandit and Thapa, 2004; Pokharel et.al. 2006) to manage these conflicts. "Conflict is common in the use and management of these natural resources. Therefore management of

\footnotetext{
${ }^{1}$ Natural Resources Management Consultant, MEH Consultants (P) Ltd. Kathmandu, Nepal.

E-mail: ganeshraj.acharya@gmail.com

${ }^{2}$ Programme Officer, RECOFTC, Thailand. E-mail: yurdi2002@yahoo.com
} 
conflict is crucial to improve the performance of natural resources management and to achieve sustainable use of natural resources" (Uprety, 2001).

\section{Materials and methods}

\section{Theoretical study}

Conflict has always been a part of human life (Yasmi, 2007; Uprety, 2006; Martin, 2005; Takacs, 2001; Hill, 1982) and it has been defined in different ways. Some scholars perceive conflict as a potential for both positive and negative outcome with creative or destructive manifestations (Abu-Nimer, 2001; Miall et.al.1999; Swaminathan, 1999; Van De Vliert et.al., 1999; Ayling and Kelly, 1997; Chan and Yu, 1985; Hill, 1982). Similarly others claim it as mostly negative with certain context (Banjade and Timsina, 2005; Upreti, 2004).

Blake and Mouton's managerial grid has strong influence on the conflict management study (Song et.al., 2006; Dyer and Song, 1998) and is a leading thesis on conflict management (Kabanoff, 1987; Pheng and Lee, 1997; Pruitt and Rubin, 1986; Thomas, 1977; Rahim, 1983; Shockley-Zalabak, 1988; Van de Vliert \& Prein, 1989: as cited in Van de vliert and Kabanoff, 1990). According to McQueen (2005), the Managerial Grid also addresses improved decision making and problem solving; manages meetings; manages time; builds better team; gets the best answer instead of being simply adequate; and manages change effectively among others. Blake and Mouton's managerial grid is empirically proven (Holt and DeVore, 2005; Pheng and Lee, 1997; van de Vliert and Euwema, 1994; Rahim 1983; Thomas 1977).

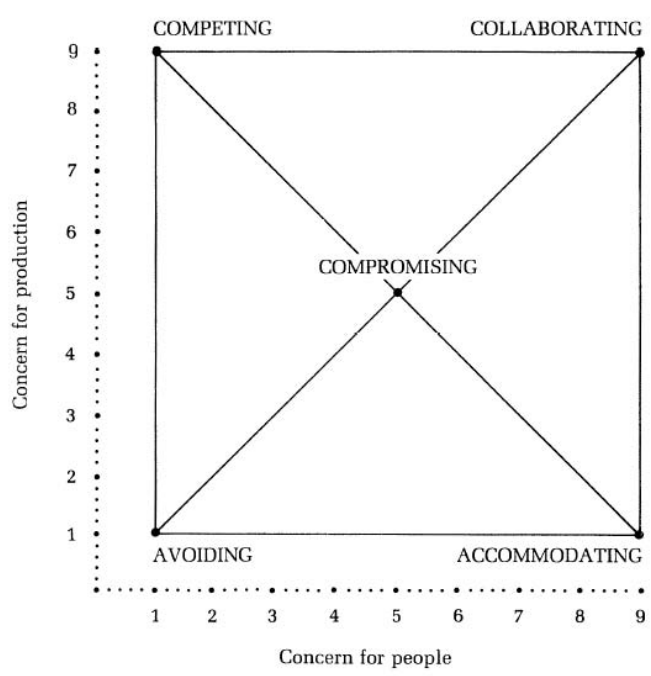

(Adapted from Van De Vliert and Kabanoff, 1990)

Fig. 1: Blake and Mouton's Managerial grid

\section{Collaborating}

It is also known as problem solving. Work accomplishment is from committed people; interdependence through a "common stake" in organization purpose leads to relationship of trust and respect (Blake and Mouton, 1968).

\section{Compromising}

Adequate organization performance is possible through balancing the necessity to get out work with maintaining morale of people at a satisfactory level (Blake and Mouton, 1968).

\section{Avoiding}

It is also known as withdrawing. Exertion of minimum effort to get required work done is appropriate to sustain organization membership (Blake and Mouton, 1968).

\section{Accommodating}

It is also known as smoothing. Thoughtful attention to needs of people for satisfying relationships leads to a comfortable friendly organization atmosphere and work tempo (Blake and Mouton, 1968).

\section{Forcing}

It is also known as competing. Individualistic choose forcing as a conflict style (Holt and DeVore, 2005).

\section{Data Collection}

Primary Data was collected through Semi Structured Interview (SSI), Focus Group Discussion (FGD), Expert's Consultation and Observation. Informal interview was also carried out to get more information. Empirical research was carried out in four CFs of Dang district where two CFs were relatively larger in size and other two were smaller. A number of interview also varied according to the size of CF. In large CFs, 30 interviews were conducted. Similarly 20 interviews were taken in each small CF. Altogether 100 respondents were selected randomly for SSI. The idea of saturation of interview is the point at which no new information or themes are obtained in data (Guest et.al. 2006). The unit of the research was mostly the individual; and in case of existing or former UGC personnel they were represented as member of institution rather than just an individual. Secondary data were collected from CF records in the study area, Central Bureau of Statistics (CBS), DFO and ranger's office in the area and other line agencies and libraries. 


\section{Data analysis}

The interview text was condensed, categorized, coded and recorded according to the following themes: conflict between UGC and user, and conflict among user and strategies to manage conflict (five strategy instruments: collaborating, compromising, avoiding, accommodating, and forcing).

The final code is looked like $C F_{X Y Z-i}$-conflict type-theme -strategy

which means:

- $\mathrm{CF}$ is $\mathrm{xyz}$

- $i$ th respondent from XYZ community forest of study area

- conflict types are conflict between UGC and users and conflict among users

- strategies are Avoiding (AV), Compromising $(\mathrm{CM})$, Collaborating (CL), Forcing (FO) and Accommodating (AC).

\section{Understanding study area}

Dang district lies in Rapti Zone of Midwestern Development Region of Nepal. Altogether four CFs were studied for this research purpose. Two of them namely Pandaweshwor CF and Raja CF are larger $\mathrm{CFs}$ whereas Kartikerani $\mathrm{CF}$ and Gadibara CF were smaller CFs in the area. Similarly larger $\mathrm{CF}$ s were from Churia region of Dang district where as smaller $\mathrm{CFs}$ were from Mahabharat region of same district. Larger CFs in Dang those were chosen for the study were found to be similar in character on many respects. Firstly, they were from Churia region; they were larger in size; more ethnic population of Dang district, mostly tharus, were its users and CFs were in remote area. Similarly smaller CFs chosen for study were also found similar in character. These forests were from Mahabharata region; they were smaller in size; relatively lesser tharu ethnic people were their users and CFs were in accessible area comparatively.

\section{Results and discussion}

\section{Strategy among User Group Committee and users}

The strategies adopted by larger and smaller CFs have been presented below on percentage. The former value on each category indicates the strategy adopted by larger $\mathrm{CFs}$ and the latter value on each category indicates the strategy adopted by smaller CFs.

\section{Strategy for benefit sharing}

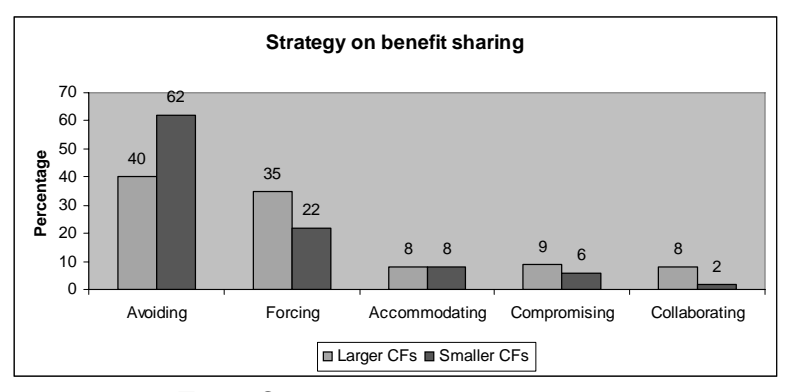

Fig: 2 Strategy on benefit sharing

Avoiding strategy is the mostly often used strategy in both larger and smaller CFs. Especially in larger $\mathrm{CFs}$, UGC preferred to use avoiding strategies in dalit related issues. They rarely admit the issues of dalit such as free access on grass, firewood and timber. UGC personnel also ignore their demands for reducing price on firewood and timber when available if free of cost to them.

In one of the larger CFs, receipt for grass, firewood and timber used to be distributed only from chairperson's home. UGC ignored the difficulty that users had to face on getting receipt. Users had to spend a lot of time to receive it because it is not always possible to meet chairperson at home. If $\mathrm{s} /$ he is not available they could not get forest resource. UGC did not consider this inconvenience to the user as a problem. Although users were not happy with such behaviour of the chairperson, they were indifferent and did not make this as an issue and protest against it. They simply wanted to get rid of such possible discussions with chairperson or they use avoiding strategy with UGC.

A high level of fee (NRs 2500) imposed by UGC as an avoiding strategy by the UGC towards newly entered users. Not all people can pay this amount because this is a large amount for subsistence living people. Activities such as 'penalizing money in CF' was not preferred by users since they did not want to confront with UGC. So their preferred stance was always on avoiding or trying to put such conflicts under carpet.

However, the UGC preferred to use forcing strategy in the resource use related issues. They imposed price on grass, firewood and thatch grass. The UGC preferred to implement regulations that they consider is 'right' at any cost. In the Pandaweshwor CF (previously), the UGC also levied money on firewood used for last rites without being sensitve to the 
humanitarian concern. Recently this levy was relaxed by the new UGC and so users no longer have to pay money for cremation.

In contrast to larger CFs, there was little grass available in smaller CFs. Similarly other resources such as firewood and timber were also not much available in comparison to larger CFs. Thus, this made lesser use of forcing strategy in smaller CFs. It was also revealed from the study that forcing strategy was more frequently in use on larger CFs than smaller CFs.

The overall strategic mechanism to run CFs is based on its constitution. The work plans and constitution of CF were found more directed towards the penalizing a person if some one was found guilty or not cooperating with CF regulations. Similarly if domestic animals of user enter into the $\mathrm{CF}$, it is punishable by some money penalty. In the same way in almost in every situation, may it be a rule breaking or any other forms of behaviour; the response was oriented more towards the penalizing policy. The watcher of CFs had authority to snatch illegal wood cutter's tools. Forcing strategy by watchers towards its users is also a UGC strategy in a indirect way. Sometimes UGC defends its approach that UGC adopts with users. The price on grass can be taken as its example. Imposing money penalty on grass, a forcing strategy, was claimed by UGC as a necessary step to generate the salary of watchers.

Accommodation has been practiced by UGC in the social activities such as firewood for last rites and marriage and similar social rituals. For such social rituals, either users do not have to pay money for forest product or they have easier access on it. However in one of the larger CFs earlier, UGC used to impose money for users for the use of last rites but recent UGC formed has relaxed this provision. "If a user devotes his life in CF activity, is it wise to exact money from him, for his/her last rites?" a user was questioning about the rationale of this provision. These types of adjustments were available on both CFs. In larger $\mathrm{CFs}$, these adjustments were made later because UGC of these CFs are gradually developing them into socially responsible. In the smaller $\mathrm{CF}$, it already existed because resource was lesser and focus of UGC was equally for forest concern and people concern.

Realizing this, a large number of users in Raja CF, UGC have formed sub committees in different villages. These sub committees play crucial role on information dissemination between UGC and user. Actually these sub committees are a kind of compromise between UGC and user about resource/ power sharing. Similarly in smaller CFs, users who need firewood and timber discuss with UGC and come with a compromise about "who actually has a genuine need for timber and fuel wood." Finally they reach a conclusion on who should be provided timber and fuel wood at this time etc.

Already existing receipt distribution system in one of the large CFs where only chairperson was assigned the authority to distribute receipt was revised later by the new UGC formed. CF began to distribute receipts from different places of $\mathrm{CF}$ in accordance to constitution and work plan. This type of collaboration between UGC and user where humanitarian concern was also addressed became an example how users and UGC develop collaborating strategy through consensus. It also provided them opportunity to learn from past mistake.

Similarly one of the land disputes between UGC and user in Kartike CF was resolved after UGC, DFO and FECOFUN talked about it and the encroached land was reclaimed back as $\mathrm{CF}$. In this way UGC convinced the encroaching users to return its CF land. This conflict management mechanism followed the collaborating strategy where consensus was developed and intruding trespasser was also not penalized.

\section{Strategy among the users}

The percentage of overall strategy adopted in larger and smaller CFs has been presented below. On each category below, former value indicates the strategy of the larger CFs and corresponding latter value indicates the strategy adopted by smaller CFs.

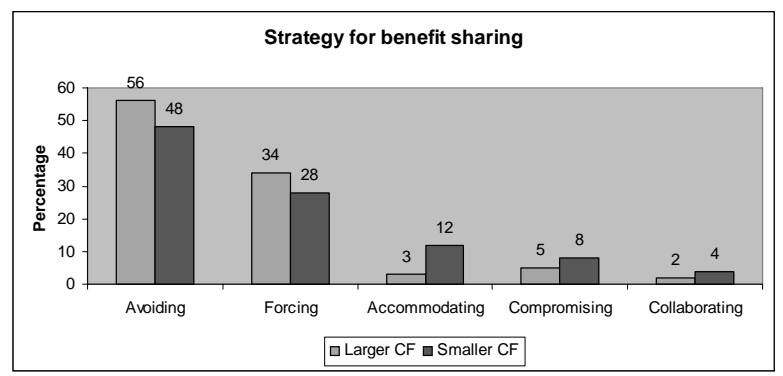

Fig. 3: Strategy on benefit sharing

General users show concern about the CF issues but they were found indifferent when it needs some concrete work to be undertaken by them. For an 
example, they show concern on benefit sharing such as firewood and grass where they demand free access on these forest resources but they rarely raise voices against the user who are more powerful and whose voice can make change. People who feel impaired by firewood and grass concern do not want to raise these issues because they do not want to take issue ahead. This tendency of not trying to be involved in direct discussions has contributed higher percentage of avoiding strategy among users. Users know that they have been impaired but they do not want to take any action against it. Users living outside of CF considered people living inside $\mathrm{CF}$ as $\mathrm{CF}$ rule violators. While people inside the $\mathrm{CF}$ also feel that they are not getting much attention. They feel that other users outside the $\mathrm{CF}$ do not recognize the genuineness of their problem. Some users of Raja $\mathrm{CF}$ who were getting benefit from two $\mathrm{CF}$ s were also not willing to cooperate with rest of the users. These users were reaping benefit from two CFs but other users were simply being discarded. Users who were getting double benefit were using avoiding strategy to neglect the concern of other users.

The Forcing strategy was mostly observed in dalit issues where people use positional and personnel power to influence them. Imposing high amount of money (NRs 2500) for newly entered members in $\mathrm{CF}$ was also considered as impairment from new user's perspective. They say such a large amount of money for them is not justifiable. However other users do not support this idea. The other users claim that new users must have to pay this amount if they are interested to join as CF as users. According to old users, forest has been protected by them and new users must have to pay for it. In this way older users impose money to new users. However older users claim that $\mathrm{CF}$ has been managed by them so it is justifiable to impose money for new users. This situation was observed both in larger and smaller CFs.

Distant users have been incorporated in CF recently. This is mostly meant to provide them opportunity for agricultural implements from CF. This situation has contributed accommodating strategy addressing distant user's need in CF. However the stake of distant people is limited in comparison to close users where close users have relatively easier access to CF.

Similarly Pandaweshwor CF has a provision of paying money for each head load of grass. Each time they go to $\mathrm{CF}$ users have to pay money for grass. However this provision is not applied for the people who live inside the CF. Such type of users has to pay a lump sum amount of money once (NRs. 100) for one year and they are eligible to take any amount of grass from the forest. This provision has been found arranged under accommodating provision where UGC want to make people inside the CF happy because if they are not provided such éasy' provision they may create problem in $\mathrm{CF}$.

In smaller $\mathrm{CF}$ s, sometimes they have to sell their trees to meet salary of the watcher. It is mostly the case of small CFs where UGC does not get any revenue from $\mathrm{CF}$ such as grass, thatch revenue. For this reason, they make an adjustment to meet salary for watchers realizing compromising strategy. In Kartikerani CF, watcher's salary was paid selling Eucalyptus tree species in CF. The problem of salary was resolved for the time being. It is not a lasting solution however. They have to create an income opportunity in $\mathrm{CF}$ to make a permanent solution for issues such as watcher's salary.

Recent recruitment of forest watcher in Pandaweshwor CF and appointment of office secretary were examples of collaborating approach. In the past this type of jobs also used to be serious issues among users. This time, during this recruitment, users were convinced in the selection process, it was based on standard norm developed through general assembly.

\section{Discussion}

This relation of conflict related to benefit sharing in CF has been supported by number of literatures (Gautam and Devoe, 2002; Straede and Helles, 2000). One of the focuses of users on benefit sharing is thatch and grass because it is important for them. Grass is also important for livestock in rural area (Straede and Helles, 2000). While analyzing the user's concern about the demand of users for free allocation of grass from forest on one hand was right because CF was meant for meeting their livelihood. CF has been adopted basically to meet these objectives. On the other hand it is equally important to note that resource can not be allocated free of cost because of its possible misappropriation (Hardin, 1968).

If we look at imposing money for grass by UGC as a step that obstructs users from getting forest resource, probably it is not logical because UGC has to give salary for watchers and meet other office expenses 
of CF. The money generated by selling grass is used for this purpose. It was really interesting to note that $\mathrm{CF}$ with more resource (i.e. larger $\mathrm{CF}$ ) has more conflicts in comparison to $\mathrm{CF}$ with lesser resource (smaller CFs). Such relation of resource and conflict has also been found widely supported (Le Billion, 2001; Acharya, 2002a; De Jong et.al., 2006; Humphreys, 2005) where economic and political elites try to obtain control over forests trying to adjust to the legislation that favors communal forestry.

The finding of this research that conflict exists due to uneven benefit sharing between rich and poor members is a critical point that needs to be discussed. It challenges a common notion that poor are benefiting from CF but also is a serious issue to be dealt. The uneven distribution of benefit is also supported by the findings of Adhikari (2005) where he finds that poorer households in forest-dependent communities obtain much less value from CFs than middle-income and rich households.

Similarly the allocation of fire wood and timber receipt only from UGC chairperson' home is not justifiable. It is not possible to visit chairperson's home every time to get forest product and it is against the 'equal access for all users' mission. Similarly the issue raised by some users on equal money imposing for both richer and poorer is logical. There should be special privilege on poor about benefit sharing issues. Timsina (2003) and Nightingale (2003) elaborate findings where the permits for timber and firewood in CF have added an extra burden to poor.

Concern for charcoal for iron workers are however genuine but equally it is a challenge meet their demand. Iron worker claim that they were receiving firewood for coal in forest since distant past. The livelihood of these people depended upon the iron working so UGC needs to address this conflict issue.

Involvement of distant users is also critical issue in CF. Distant users is also aware about their rights. The logic behind inclusion of distant user in community forestry recently is the counter strategy on government's recent programme collaborative forestry which government is thinking alternative to CF in Terai area (Bampton, 2003; Bhattarai, 2006).

Even if it is accepted that user's demand to graze their cattle inside CF is genuine, it is most likely not a solution. An open cattle grazing is considered a serious issue in the CF. However most frequently used penalizing policy on animal's entry on forest was also considered as an important triggering factor for conflict between users and UGC. There was a strict rule on CF that allowed UGC to impose money if animals enter into the CF. Such types of rules also made people confronted towards the UGC.

The imposing of an entry charge for the first time as a membership in CF is not uncommon. Similarly it is natural to pay some amount of extra charge while entering into a position first time. The important thing is whether it is equal for rich new comer and poor new comer or it should be equity based considering special consideration to poor people, this needs to be answered. As far as CFUG is concerned they are indifferent about it and impose equal money for all.

\section{Conclusions}

Conflict is not exclusive among two conflict types. Conflict issues identified between UGC and user were also uncovered in conflict between users. CF benefit sharing is based on equality and it does not realize difference on economical condition between poor users and rich users. This tendency of not considering poor user has created uneven benefit sharing in CF. It is favoring rich users with more access on forest resource while lesser access for poor users. As a result this difference has generated conflict on benefit sharing among UGC and users.

The concept of involving distant people also as its users has been found in CFs now. Such kind of distant people's involvement in CF is basically to meet user's demand on firewood and timber. The success of distant people involvement was also challenging an existing debate that terai forest can not meet demand of distant users. In fact this study also suggests distant users can be allocated CF product as users.

Avoiding and forcing are dominant strategies in CF. Mostly avoiding strategy was major strategy found to be on use in CF and second major strategy in use was forcing. The use of compromising and accommodation strategy is almost identical. These strategies were used in lesser number than avoiding strategy.

Collaborating strategy has been found a least used strategy to manage conflict in the CF. The claim that $\mathrm{CF}$ is managing its conflict well is now on question. The study reveals that collaborating strategy hardly been achieved on managing conflict in CF. 


\section{Recommendations}

Poor members of the CF should be given priority in meeting their forest needs. This priority must be reflected in the documents such as CF work plan and constitution so that their benefit sharing is secured. Study shows that distant users can be accommodated in CF. On one hand it meets their $\mathrm{CF}$ needs and on the other hand it guarantees their traditional rights. For this reason, CF should also involve distant users.

Realizing the high level of application of avoiding and forcing strategy, it is recommended that CF has to rethink about existing conflict management strategies so that it can improve performance. Collaborating strategy is almost not in use. It is recommended that collaborating strategy should be adopted in the CF recognizing both outcome and human concern. Similarly if Blake and Mouton's managerial grid theory is used at higher scale covering larger area it will generate knowledge to assist natural resource policy makers and to improve CF performance better.

\section{Acknowledgements}

We would like to acknowledge Prof. Dr. Bas Arts, Wageningen University for his constructive comments, Mr. Pashupati Nath Koirala, Department of Forest; Mr. Shyam Sundar Sharma and Mr. Govinda Man Tamrakar, Directors of MEH Consultants; and Mr. Bijendra Basnyat, Consultant, NARMA Consultancy for their input, help and suggestions.

\section{References}

Abu-Nimer, M. 2001. Conflict resolution, culture, and religion: towards a training model of interreligious peace building. Journal of Peace Research 38 (36): 685-704.

Acharya, G.R. 2007a. Influence of non state actor on state: a study of FECOFUN and Government in Nepal. MSc thesis, Wageningen University, The Netherlands.

Acharya, G.R. 2007b. Conflict management in community forestry: a study of community forests in Nepal. MSc thesis, Wageningen University, The Netherlands.

Acharya, G.R. 2002a. Nepal's buffer zone forest looking sustainable directions (a case study of buffer zone forests from Royal Bardia National Park); MSc thesis, Centre for Advanced Studies/ Nepal Engineering College, Pokhara University, Nepal.

Acharya, K.P. 2002b. Twenty-four years of community forestry in Nepal. International Forestry Review: 4 (2): 149-156.

Adhikari, B. 2005. Poverty, property rights and collective action: understanding the distributive aspects of common property resource management. Environment and Development Economics 10: 7-31.

Agrawal, A. and Ostrom, E. (2001). Collective action, property rights, and decentralization in resource use in India and Nepal. Politics and Society 29 (4): 485-514.

Ayling, R.D. and Kelly, K. 1997. Dealing with conflict: natural resources and dispute resolution. Common Wealth. Forestry Review 76 (3): 182-185.

Bampton, J.F.R. 2003. District forest coordination committee: an emerging multistakeholder platform for collaborative forest management in Nepal's Terai. Journal of Forest and Livelihood 2 (2): pp 35-47.

Banjade, M.R. and Timsina, N.P. (2005). Impact of armed conflict in community forestry of Nepal. ETFRN News: 81-83.

Banjade, M.R., Timsina, N.P., Neupane, H.R., Bhandari, K., Bhattarai, T. and Rana, S.K. 2006. Transforming agency and structure of facilitating pro-poor governance in community forestry. Journal of Forest and Livelihood 5 (1): 22-33.

Bhattarai, B. 2006. Widening the gap between terai and hill farmers in Nepal: the implications of the new forest policy 2000 in: Hanging in the balance: equity in community-based natural resource management natural resource management in Asia (eds.) Mahanty, S., J. Fox, M. Nurse, P. Stephen and L. McLees et.al., RECOFTC and the East-West Center, 143161.

Blake, R.R. and Mouton, J.S. 1968. The managerial grid, Gulf publishing Company, Houston.

Chakraborty, R.N. 2001. Stability and outcomes of common property institutions in forestry: evidence from terai region of Nepal. Ecological Economics 36: 341-353. 
Chan, S.J. and Yu, P.L. 1985. A dynamic conflict resolution model: acceptability of alternatives and conflict solvability. Journal of Optimization Theory and Applications 47 (3): 269-284.

Chhetri, R.B. 2006. From protection to poverty reduction: a review of forestry policies and practices in Nepal. Journal of Forest and Livelibood 5 (1): pp 66-77.

De Jong, W., Ruiz, S. and Becker, M. 2006. Conflicts and communal forest management in northern Bolivia. Forest Policy and Economics 8: 447-457.

Dyer, B. and Song, M. 1998. Innovation strategy and sanctioned conflict: a new edge in innovation? $J$ Prod Innov Manag: 505-519.

Fisher, R. J. 1995. Collaborative management of forests for conservation and development, IUCN and WWF.

Gautam K.H. and Devoe, N.N. 2002. Conflicts between policy and local people in valuing nontimber forest products: perspectives from Nepal. Journal of Forest and Livelihood 2 (1): 43-52.

Gautam, K.H. 2006. Forestry, politicians and power - perspectives from Nepal's forest policy. Forest Policy and Economics 8: 175-182.

Gilmour, D.A. and Fisher, R.J. 1991. Villagers, forests and foresters: the philosophy, process and practice of community forestry in Nepal, Sahayogi press pvt. Ltd, Kathmandu.

Guest, G., Bunce, A. and Johnson, L. 2006. How many interviews are enough? An experiment with data saturation and viability. Field Methods 18 (1): 59-82.

Hardin, G. 1968. The tragedy of commons Science 162: $1243-1248$.

Hill, B.J. 1982. An analysis of conflict resolution techniques from problem-solving workshops to theory; Journal of Conflict Resolution 26 (1): 109138.

Holt, J.L. and DeVore, C.J. 2005. Culture, gender, organizational role, and styles of conflict resolution: a meta analysis. International Journal of Intercultural Relations 29:165-196.

Humphreys, M. 2005. Natural resources, conflict, and conflict resolution. Journal of Conflict Resolution 49 (4): 508-537.
Joshi, A.L. year not mentioned. National forest policy framework and conflict management: a overview, community forestry unit, integrating conflict management considerations into national policy frameworks (FAO): 117-131.

Kabanoff, B. 1987. Predictive validity of the MODE conflict instrument. Journal of Applied Psychology 72(1): 160-163.

Le Billion, P. 2001. The political ecology of war: natural resources and armed conflicts: Political Geography 20: 561-584.

Martin, A. 2005. Environmental conflict between refugee and host communities. Journal of Peace Research 42 (3): pp 329-346.

McQueen, D. 2005. What is grid? A long term user defines grid experience. Grid International, Inc.: $1-4$.

Miall, H., Ramsbotham, O. and Woodhouse, T. 1999. The contemporary conflict resolution, Polity press, Cambridge.

Nightingale, A. 2003. Nature-society and development: social, cultural and ecological change in Nepal. Geoforum 34: 525-540.

Pandit, B.H. and Thapa, G.B. 2004. Poverty and resource degradation under different community forest resource management systems in the mountain of Nepal. Society and Natural Resources 17: $1-16$.

Pheng, L.S. and Lee, B.S.K. 1997. "Managerial grid" and Zhu Liang's "Art of management": integration for effective project management. Management Decision 35 (5): 382-391.

Pokharel, B., Paudel, D., Branney, P., Khatri, D.B. and Nurse, M. 2006. Reconstructing the concept of forest based enterprise development in Nepal: towards a pro poor approach. Journal of Forest and Livelihood 5(1): 53-65.

Pokharel, B.K. 2001. Livelihoods, economic opportunities and equity: community forestry and people's livelihood. Journal of Forestry and Livelihood 1: 16-18.

Pruitt, D.G. and Rubin, J.Z. 1986. Social conflict: escalation, stalemate, settlement, Random house, New York. 
Rahim, M.A. 1983. A measures of styles of handling interpersonal conflict. Academy of Management Journal 26 (2): 368-376.

Rana, B. 2004. Understanding conflict between government and resource users: a multi criteria analysis of community forestry performance in Saptari district, Nepal; MSc Thesis, ITC.

Shockley-Zalabak, P. 1988. Assessing Hall conflict management survey. Management Communication Quarterly 1 (3): 302-320.

Shrestha, K.B. 1996. Community forestry in Nepal: an overview of conflicts, discussion, paper series no. MNR 96/2.

Song, M., Dyer, B. and Thieme, R.J. 2006. Conflict management and innovation performance: an integrated contingency perspective. Journal of the Academy of Marketing Science 34 (3): 341-356.

Straede, S. and Helles, F. 2000. Park-people conflict resolution in Royal Chitwan National Park, Nepal. Journal of Environmental Conservation 27 (4): 368-381.

Swaminathan, S. 1999. Time, power, and democratic transitions. Journal of Conflict Resolution 43 (2): 178191.

Takacs, K. 2001. Structural embeddedness and intergroup conflict. Journal of Conflict Resolution 45 (6): 743-769.

Thomas, K.W. 1977. Towards multi-dimensional values in teaching: the examples of conflict behaviors. The Academy of Management Review 2 (3): 484-490.
Timsina, N.P. 2003. Promoting social justice and conserving montane forest environments: a case study of Nepal's community forestry programme. The Geographical Journal 169 (3): 236-242.

Upreti, B.R. 2001. Conflict management in natural resources: a study of land, water and forest conflicts in Nepal. PhD dissertation, Wageningen University.

Upreti, B.R. 2004. Resource conflicts and conflict resolution in Nepal. Journal of Mountain Research and Development 24 (1): 60-66.

Uprety, D.R. 2006. Conflict in natural resources management- examples from community forestry. Jahrbuch der Österreichischen Gesellschaft für Agrarökonomie 15: 143-155

Van de Vliert, E. and Euwema, M.C. 1994. Interpersonal relations and group processes agreeableness and activeness as components of conflict behaviors. Journal of Personality and Social Psychology 66 (4): 674-687.

Van De Vliert, E., Nauta, A., Giebels, E. and Janssen, O. 1999. Constructive conflict at work. Journal of Organizational Behaviour 20: 475-491.

Vliert, E.V.D. and Kabanoff, B. (1990). Towards theory based measures of conflict management. Academy of Management Journal 33 (1), pp 199-209.

Yasmi, Y. 2007. Institutionalization of conflict capability in the management of natural resources: theoretical perspectives and empirical experience in Indonesia. PhD thesis, Wageningen University, The Netherlands. 